\title{
Long-term Effect of pH on B-Cell Function in Isolated Islets of Langerhans in Tissue Culture
}

\author{
J. Brunstedt and J. H. Nielsen \\ Steno Memorial Hospital, Research Laboratory, Gentofte, Denmark
}

Summary. Collagenase isolated mouse pancreatic islets were maintained in tissue culture for up to 5 months in a culture medium buffered with Hepes and the $\mathrm{pH}$ varying between 6.8 and 7.6. The amount of insulin released into the medium and the insulin response to glucose and glucose plus theophylline were measured during the culture period. It was found that islets cultured at $\mathrm{pH} 7.2$ maintained the ability to release insulin into the medium for at least 5 months, which was longer than islets cultured at the other $\mathrm{pH}$ values. During the first weeks, the islets cultured at $\mathrm{pH} 7.6$ had a higher response to both glucose and glucose plus theophylline than islets cultured at the other $\mathrm{pH}$ values, but later they lost their insulin releasing ability.

Key words: Pancreatic islets, tissue culture, insulin release, $\mathrm{pH}$-values, free-floating.

The maintenance of islets of Langerhans in a functional state for extended periods of time would be a valuable tool for collecting material for transplantation and for studying the effect of various hormones and metabolites on islet function in vitro.

There have been several reports dealing with long-term survival of isolated pancreatic islets in tissue culture $[5,11,12,18,20,21]$ and a number of factors affecting the survival and function of the islets have been studied, e. g. glucose [1], media [3] and sera $[8,17]$, but little attention has been paid to the effect of the $\mathrm{pH}$ of the culture medium. In tissue culture of pancreatic islets, the $\mathrm{pH}$ is normally maintained in the range of 7.2 to 7.4 by using a culture medium buffered with sodium bicarbonate in a $\mathrm{CO}_{2}-$ incubator. Utilization of Hepes (N-2-hydroxyethyl-
piperazine-N'-2-ethanesulphonic acid) as an alternative buffer to bicarbonate in tissue culture has become common; it does not require a $\mathrm{CO}_{2}$-enriched atmosphere and it is possible to vary the $\mathrm{pH}$ in the culture medium.

In this report we describe the effect of $\mathrm{pH}$ in the culture medium on insulin secretion from isolated mouse pancreatic islets in free floating culture, a recently described technique $[3,8]$ which permits survival and function of isolated islets for many months [18].

\section{Materials and Methods}

\section{Tissue Culture}

Isolated islets were obtained by a collagenase method [4] from over-night fasted male NMRI mice, with a body weight of $25-30 \mathrm{~g}$. Briefly, pancreases from 2 animals were cut into small pieces, which were suspended in $4 \mathrm{ml}$ of Hank's Balanced Salt Solution, HBSS, with $25 \mathrm{mmol} / \mathrm{l}$ Hepes adjusted to $\mathrm{pH} 7.4$ (Flow Laboratories) containing $2 \mathrm{mg} / \mathrm{ml}$ collagenase (Type I, Sigma Chemical Company) in a glass scintillation vial. After shaking the suspension in a water bath at $37^{\circ} \mathrm{C}$ and $250 \mathrm{rpm}$ (reciprocating) for $20 \mathrm{~min}$, the digested tissue was washed with cold HBSS and the islets were collected with the aid of a braking pipette and transferred to plastic Petri dishes (NUNC, Denmark) with $5 \mathrm{ml}$ culture medium (100 islets per dish). The Petri dishes are made of a type of plastic which does not permit attachment of the islets. The culture medium consisted of RPMI 1640 with $20 \mathrm{mmol} / 1$ Hepes (Flow Laboratories) supplemented with $4.1 \mathrm{mmol} / 1 \mathrm{NaHCO}_{3}$, $10000 \mathrm{U} / \mathrm{ml}$ penicillin, $100 \mathrm{mg} / \mathrm{l}$ streptomycin and $10 \%$ non-heatinactivated newborn calf serum (Gibco Bio-cult). The glucose concentration of this culture medium was $11 \mathrm{mmol} / \mathrm{l}$. Before addition of serum, the medium was kept for $3 \mathrm{~h}$ at $37^{\circ} \mathrm{C}$; the $\mathrm{pH}$ was then adjusted with $\mathrm{HCl}$ or $\mathrm{NaOH}(1 \mathrm{~mol} / 1)$ so that it was at the desired value after addition of serum. A small increase in $\mathrm{pH}$ could be observed throughout the culture period, probably caused by escape of $\mathrm{CO}_{2}$, but this did not exceed $0.1 \mathrm{pH}$-unit. Cultures were incubated at $37^{\circ} \mathrm{C}$ in a humidified atmosphere of air and the culture medium was changed every second or third day and once a week glucose stimulated insulin release was studied in a short-term experiment. 


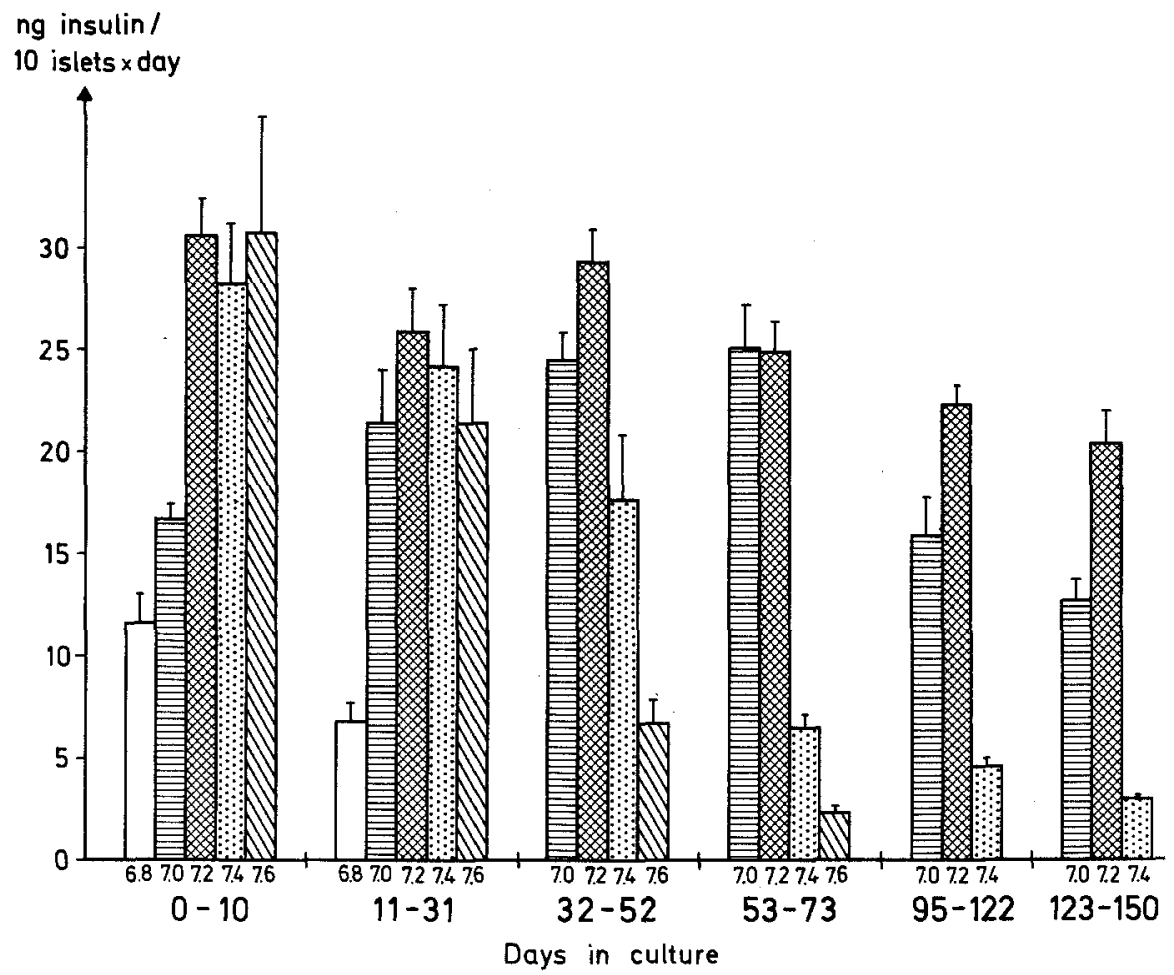

Fig. 1. Immunoreactive insulin released into the medium during culture of mouse islets at different $\mathrm{pH}$ values as shown at the bottom of each bar. Each bar represents the mean \pm SEM of 4-9 medium samples taken during the indicated period

\section{Insulin Release}

Accumulation of insulin in the culture medium was followed by determination of the insulin content in a sample taken at each medium change. For the weekly studies of short-term insulin secretion, the islets were incubated in small Petri dishes in HBSS with $25 \mathrm{mmol} / \mathrm{l}$ Hepes at $\mathrm{pH} 7.4$ (unless otherwise stated) containing $5.5 \mathrm{mmol} / 1$ glucose and $10 \%$ calf serum, final volume $2 \mathrm{ml}$, for $2 \mathrm{~h}$; subsequently the medium was changed to $22 \mathrm{mmol} / \mathrm{l}$ glucose for $1 \mathrm{~h}$, and then to $22 \mathrm{mmol} / 1$ glucose with $5 \mathrm{mmol} / 1$ theophylline. Finally, the islets were transferred to new culture medium (RPMI 1640 ) with $10 \%$ calf serum.

The samples from the culture medium and the secretory medium were stored at $-20^{\circ} \mathrm{C}$ prior to insulin assay. Insulin was determined by radioimmunoassay using the double antibody technique of Hales and Randle [9] and a crystalline mouse insulin as standard (NOVO).

\section{Results}

The effect of different $\mathrm{pH}$-values in the culture medium on release of insulin into the medium is illustrated in Figure 1. During the first weeks of culture, the insulin release was independent of $\mathrm{pH}$ from 7.2 to 7.6. Already, after one month in culture, the insulin release from islets kept at $\mathrm{pH} 6.8$ was minimal and the islets became smaller and gradually disappeared. After two months only a small amount of insulin was released from islets kept at $\mathrm{pH} 7.6$ and 7.4, but the islets were still present. Those kept at $\mathrm{pH} 7.0$ showed a decrease after 3-4 months and those at $\mathrm{pH} 7.2$ were only slightly decreased after 5 months.
Glucose-induced insulin release, in the absence of theophylline, from islets cultured at different $\mathrm{pH}$-values is shown in Figure 2. Glucose-induced insulin release was very much affected by $\mathrm{pH}$. In the first weeks of culture, the islets were stimulated to the highest insulin release when cultured at $\mathrm{pH} 7.6$, but long-term culture at this $\mathrm{pH}$ reduced insulin secretion and after 2 months of culture the islets did not respond to glucose. The basal insulin release, i. e. in $5.5 \mathrm{mmol} / 1$ glucose during the same experimental conditions, was found to be between 0.1 and $0.5 \mathrm{ng}$ insulin per ten islets and 1 hour for all cultures. Culture of islets at $\mathrm{pH} 6.8$ also reduced the glucoseinduced insulin release markedly. Islets cultured at pH 7.2 maintained their insulin-releasing ability; after 4-5 months of culture the glucose-stimulated insulin release was $70 \%$ of that of the first week, but only $40 \%$ of the maximal response, which was reached after one month in culture.

Insulin release, induced with both glucose and theophylline (Figure 3), was dependent on the $\mathrm{pH}$ in a similar way to insulin release induced with glucose alone. Islets cultured at $\mathrm{pH} 7.2$ were still able to secrete insulin after 5 months of culture to the same extent as islets cultured for one week. However, during the first 50 days of culture at $\mathrm{pH} 7.2$ there was an increase in the insulin releasing capacity in shortterm stimulations, followed by a gradual decrease.

In order to see whether variation in $\mathrm{pH}$ influences glucose-induced insulin release in short-term experi- 

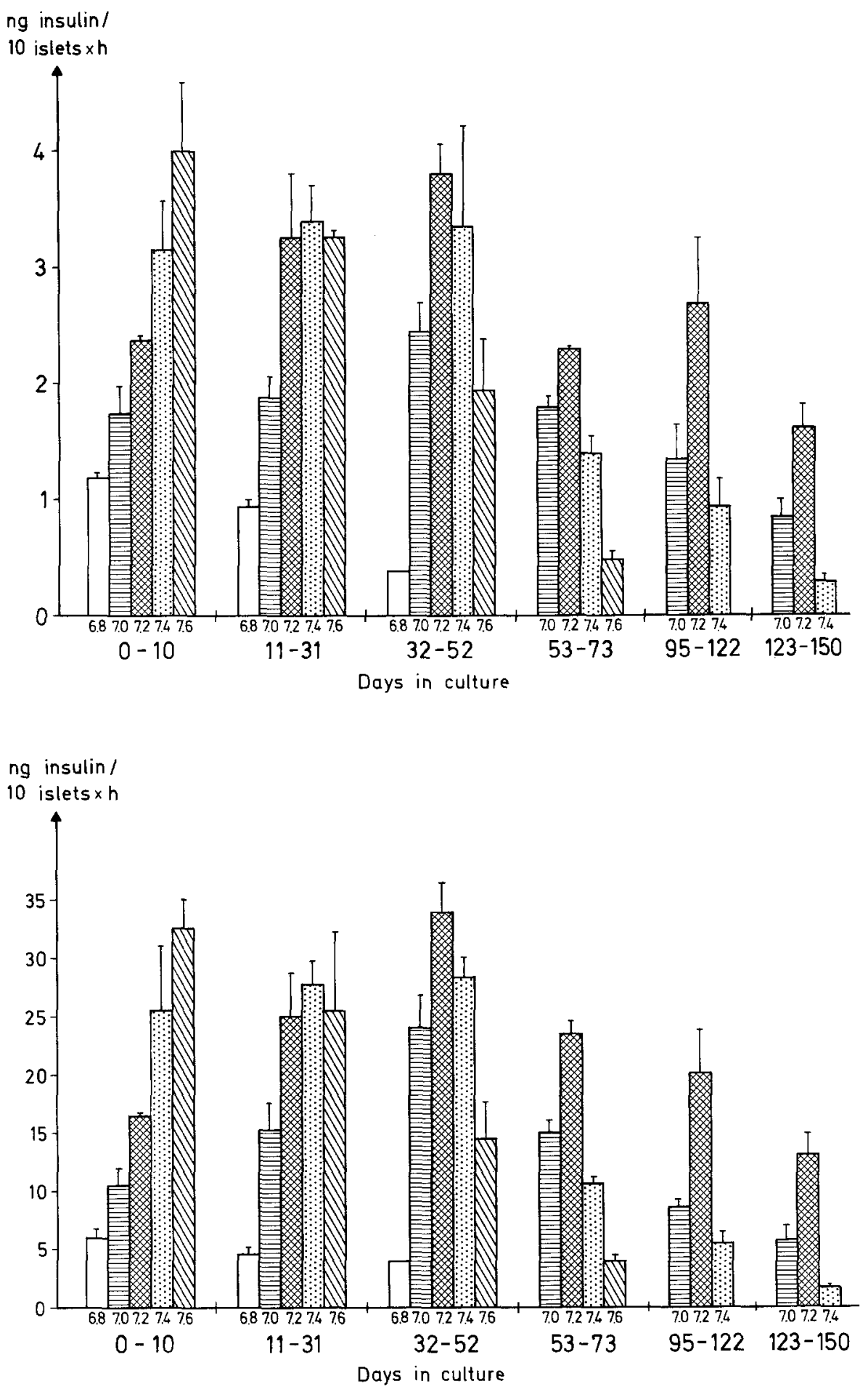

Fig. 2. Immunoreactive insulin release induced by $22 \mathrm{mmol} / 1$ glucose from mouse islets cultured in RPMI 1640 at different $\mathrm{pH}$-values, as shown at the bottom of each bar. Each bar represents the mean \pm SEM of 2-3 experiments in each period
Fig. 3. Immunoreactive insulin release induced by $22 \mathrm{mmol} / \mathrm{l}$ glucose and $5 \mathrm{mmol} / \mathrm{l}$ theophylline from mouse islets cultured in RPMI 1640 at different $\mathrm{pH}$-values, as shown at the bottom of each bar. Each bar represents the mean \pm SEM of $2-3$ experiments in each period ments, islets cultured at $\mathrm{pH} 7.2$ were subjected to glucose and glucose plus theophylline at different $\mathrm{pH}$-values (Table 1). It is seen that the $\mathrm{pH}$-value during short-term stimulation had only a minor influence on the insulin release.

Since presence of non-heat-inactivated calf serum results in loss of insulin by degradation [18], the amount of insulin given in Figure 1 are all underestimates. The degrading capacity varied only little in the present $\mathrm{pH}$-interval (data not shown). In the 1 hour release experiments (Figure 2, 3 and Table 1) the loss of insulin due to degradation is estimated to be less than $10 \%$. 
Table 1. Effect of $\mathrm{pH}$ in short-term incubations

\begin{tabular}{lll}
\hline \begin{tabular}{l} 
pH value in $\begin{array}{l}\text { short-term } \\
\text { incubations }\end{array}$ \\
\cline { 2 - 2 }
\end{tabular} & \multicolumn{2}{l}{ Insulin secretion $(\mathrm{ng} / 10$ islets $\times \mathrm{h})$} \\
\cline { 2 - 3 } & $22 \mathrm{mmol} / \mathrm{l}$ glucose & $\begin{array}{l}22 \mathrm{mmol} / \mathrm{l} \text { glucose } \\
+5 \mathrm{mmol} / \mathrm{l} \text { theophylline }\end{array}$ \\
\hline 6.5 & $3.1 \pm 0.5$ & $10.8 \pm 1.3$ \\
7.0 & $3.5 \pm 0.6$ & $15.9 \pm 0.7$ \\
7.5 & $2.7 \pm 0.2$ & $13.0 \pm 0.4$ \\
8.0 & $2.8 \pm 0.2$ & $11.9 \pm 0.7$ \\
\hline
\end{tabular}

Immunoreactive insulin release induced by $22 \mathrm{mmol} / \mathrm{l}$ glucose or $22 \mathrm{mmol} / \mathrm{l}$ glucose plus $5 \mathrm{mmol} / \mathrm{l}$ theophylline at different $\mathrm{pH}$-values from mouse islets cultured in RPMI 1640 at $\mathrm{pH} 7.2$ and $10 \%$ calf serum for 15-30 days. Mean \pm SEM of 4 experiments are given

\section{Discussion}

Long-term culture of isolated islets from different species in different types of culture systems, such as perifusion in filter units [12] or capillary culture units [21], culture on cellophane in culture chambers [11] or in Microtest II trys [20], have been reported. The Petri dish method developed by Andersson et al. [2, 4 , 5] for tissue culture of pancreatic islets, for metabolic and functional studies, permits simple handling of the cultures and direct observation of the islets.

For transplantation purposes the maintenance of islets in a functional state for extended periods of time would be convenient in order to collect enough of the required tissue type, since the yield of islets from human tissue is variable [5]. The method recently described by Andersson [3], with islets in free floating culture in Petri dishes, seems very useful for storage of isolated islets in a functional state for a long time. Some of the factors affecting the survival and function of cultured islets have been investgated $[3,18]$, but the method still needs to be optimized. The presence of serum is necessary for a good survival and a normal insulin response to glucose $[2,3$, 13]. Attempts to keep islets functional in culture in the absence of serum have been done with some success with microdissected islets from ob/ob mice [6], but only when the glucose concentration of the culture medium was markedly elevated. Culture in the absence of serum prevents the islets from attaching to the bottom of the Petri dishes [6]; this seems favourable, since the islets then do not migrate to form a monolayer consisting partly of fibroblasts. However, by adding homologous serum [8] or by using bacteriological Petri dishes $[3,22]$ islets can be kept free floating with little functional change for several months [18].

Recent studies [3, 18] have shown that the RPMI 1640 medium is superior to other commercially available media in maintaining the glucose-stimulated insulin secretion for prolonged periods [18]. This medium contains higher concentrations of glucose (11 mmol/l), phosphate, and vitamins of the Bgroup than the commonly used Parker 199 medium.

In order to optimize further the conditions for maintaining isolated islets in a functional state in the free floating culture system we have studied the influence of $\mathrm{pH}$ in the culture medium. It has earlier been shown that non-transformed cells are especially sensitive to even small deviations from their optimum $\mathrm{pH}$ [7]. The culture conditions commonly used with a bicarbonate buffered medium and incubating in a $\mathrm{CO}_{2}$-incubator, do not allow easy variation in the $\mathrm{pH}$. By using an organic buffer as an alternative to bicarbonate, it is possible to vary the $\mathrm{pH}$ in the culture medium. In some studies, Hepes was found to be superior to bicarbonate $/ \mathrm{CO}_{2}$ with respect to maximal cell density and viability of a number of cell systems [19]. In this study we have used Hepes as buffer, but we have not excluded bicarbonate totally, since it is well known that bicarbonate is an essential cell nutrient [16] and it has been shown that bicarbonate is important for the glucose-stimulated insulin release [10].

The present studies indicate that the substitution of bicarbonate in part with Hepes changes neither the function of the islets nor the length of the culture period with good survival; the islets cultured at the optimum $\mathrm{pH}(7.2)$ release insulin into the medium during culture and respond to glucose loads just as well as the islets cultured in a bicarbonate buffered medium [18].

In earlier studies on freshly isolated islets Malaisse and Malaisse-Lagae [15] and Lernmark [14] found a reduction in the glucose-induced insulin release at low $\mathrm{pH}$-values $(5.0-6.3)$ and a maximal release at $\mathrm{pH}$-values of 7.4-8.0, which could be due to an alteration in the calcium influx into the betacell [15]. Similarly, Ziegler et al. [23] reported a higher insulin release from islets cultured for 2 weeks at $\mathrm{pH} 8.0$ than at $\mathrm{pH} 7.3$. These results are in agreement with the insulin release during the first week of culture (Figure 1). However, the short- term effect of $\mathrm{pH}$ on islets cultured for 2 to 4 weeks revealed only minor differences in the glucose-induced insulin release (Table 1), and long-term exposure to various $\mathrm{pH}$ resulted in loss of islets when $\mathrm{pH}$ is below 7.0 and loss of the insulin releasing capacity when $\mathrm{pH}$ is higher than 7.4. The best preservation of beta-cell function was found at $\mathrm{pH} 7.2$.

Acknowledgements. The authors thank Dr. A. Andersson for helpful advice and criticism. We also thank Mrs. K. Brunstedt, Mrs. D. Jensen and Miss R. Jørgensen for their excellent technical assistance and Mrs. H. Færgeman for her secretarial help. 


\section{References}

1. Andersson, A.: Long-term effects of glucose on insulin release and glucose oxidation by mouse pancreatic islets maintained in tissue culture. Biochem. J. 140, 377-382 (1974)

2. Andersson, A.: Tissue culture of isolated pancreatic islets. Acta Endocrinol. [Suppl.] (Kbh.) 205, 283-293 (1976)

3. Andersson, A.: Isolated mouse pancreatic islets in culture: Effects of serum and different culture media on the insulin production of the islets. Diabetologia 14, 397-404 (1978)

4. Andersson, A., Hellerström, C.: Metabolic characteristics of isolated pancreatic islets in tissue culture. Diabetes 21 [Suppl. 2],546-554 (1972)

5. Andersson, A., Borg, H., Groth, C. G., Gunnarsson, R., Hellerström, C., Lundgren, G., Westman, J., Östman, J.: Survival of isolated human islets of Langerhans maintained in tissue culture. J. Clin. Invest. 57, 1295-1301 (1976)

6. Buitrago, A., Gylfe, E., Hellman, B., Idahl, L.-A., Johansson, M.: Function of microdissected islets cultured in a chemically defined medium. I. Insulin content and release. Diabetologia 11, 535-540 (1975)

7. Eagle, H.: The effect of environmental $\mathrm{pH}$ on the growth of normal and malignant cells. J. Cell Physiol. 82, 1-8 (1973)

8. Goldman, H., Colle, E.: Human pancreatic islets in culture: Effects of supplementing the medium with homologous and heterologous serum. Science 192, 1014-1016 (1976)

9. Hales, C. N., Randle, P. J.: Immunoassay of insulin with insulin antibody precipitate. Biochem. J. 88, 137-146 (1963)

10. Henquin, J.-C., Lambert, A. E.: Bicarbonate modulation of glucose induced biphasic insulin release by rat islets. Am. J. Physiol. 231, 713-721 (1976)

11. Kostianovsky, M., Lacy, P. E., Grender, M. H., Still, M. F.: Long-term (15 days) incubation of islets of Langerhans isolated from adult rats and mice. Lab. Invest. 27, 53-61 (1972)

12. Lacy, P. E., Finke, E. H., Gonant, S., Naber, S.: Long-term perifusion of isolated rat islets in vitro. Diabetes 25, 484-493 (1976)

13. Leach, F. N., Ashworth, M. A., Barson, A. J., Milner, R. D. G.: Insulin release from human foetal pancreas in tissue culture. J. Endocrinol. 59, 65-79 (1973)

14. Lernmark, $\AA$..: Isolated mouse islets as a model for studying insulin release. Acta Diabetol. Lat. 8, 649-679 (1971)
15. Malaisse, W., Malaisse-Lagae, F.: A possible role for calcium in the stimulus-secretion coupling for glucose-induced insulin secretion. Acta Diabetol. Lat. 7 [Suppl. 1], 264-275 (1970)

16. McLimans, W. F.: The gaseous environment of the mammalian cell in culture. In: G. H. Rothblat, V. J. Cristofalo, (eds.): Growth, nutrition and metabolism of cells in culture, Vol. I, pp. 137-170. New York: Academic Press 1972

17. Nielsen, J. H., Eff, C., Deckert, T., Jensen, D., Brunstedt, K., Andersson, A.: Effect of diabetic sera on isolated islets in tissue culture. Diabetologia 13, 421 (1977)

18. Nielsen, J. H., Brunstedt, J., Andersson, A., Frimodt-Møller, C.: Preservation of beta-cell function in adult human pancreatic islets for several months in vitro. Submitted for publication

19. Shipman, C.: Evaluation of 4 (2-hydroxyethyl)-1-piperazine ethane sulfonic acid (Hepes) as a tissue culture buffer. Proc. Soc. Exp. Biol. Med. 130, 305-310 (1969)

20. Takaki, R., Ono, J., Fukuma, M., Ikegami, T.: Long-term culture of isolated pancreatic islets cells. Proc. Soc. Exp. Biol. Med. 149, 402-406 (1975)

21. Tze, W. J., Chen, L. M.: Long-term survival of adult rat islets of Langerhans in artificial capillary culture units. Diabetes 26, 185-191 (1977)

22. Ziegler, B., Hahn, H.-J., Ziegler, M., Fiedler, H.: Successful cultivation of isolated islets of Langerhans without attachment: Relationship between glucose- and theophyllineinduced insulin release and insulin content in rat islets after cultivation. Endokrinologie 69, 103-111 (1977)

23. Ziegler, B., Butter, R., Ziegler, M., Hahn, H. J., Fiedler, H.: Untersuchungen an Langerhans'schen Inseln in vitro, 10. Kultivierung Langerhans'scher Inseln der Wisterratte und deren Insulinsekretionsverhalten. Acta Biol. Med. Ger. 32, 503-511 (1974)

Received: January 31, 1978

and in revised form: April 12, 1978

Dr. J. Brunstedt

Steno Memorial Hospital

Research Laboratory

Niels Steensensvej 6

DK-2820 Gentofte

Denmark 